\title{
Erzurum İli Meralarında Doğal Olarak Yetişen Bazı Buğdaygil Yem Bitkilerinin In Vitro Gaz Üretim Değerlerinin Belirlenmesi
}

\author{
Esra GÜRSOY ${ }^{1}$ \\ Muhlis MACIT ${ }^{2 *}$ \\ ${ }^{1}$ İl Gıda, Tarım ve Hayvancılık Müdürlüğü, Erzincan \\ ${ }^{2}$ Atatürk Üniversitesi Ziraat Fakültesi Zootekni Bölümü, 25240 Erzurum \\ *e-posta: mmacit@atauni.edu.tr; Tel: 04422312204
}

\begin{abstract}
Özet: Erzurum ilinde doğal olarak yetişen bazı buğdaygil yem bitkilerinin in vitro gaz üretim miktarları, gaz üretim parametreleri ve organik madde sindirilebilirlikleri (OMS) ile metabolik enerji (ME), net enerji laktasyon (NEL) ve besin maddeleri bileşimlerinin belirlenmesi amacıyla yürütülen çalışmada, 8 adet buğdaygil yem bitkisi [domuz ayrığı (Dactylis glomerata), adi otlak ayrı̆̆ı (Agropyron cristatum), kırmızı yumak (Festuca rubra), koyun yumağı (Festuca ovina), alaca brom (Bromus variegatus), mavi ayrık (Agropyron intermedium), çayır kelp kuyruğu (Phleum pratense), çayır salkım otu (Poa pratensis)] kullanılmıştır. Ín vitro gaz üretim tekniğinde rumen sıvısı için 8 yaşında rumen kanülü takılmış bir baş Holstein ırkı boğa kullanılmıştır. Ín vitro gaz ölçümleri 3, 6, 9, 12, 24, 48, 72 ve 96 saat aralıklarla yapılmıştır. Buğdaygil yem bitkileri arasında kimyasal bileşim bakımından önemli farklılıklar gözlenmiştir $(\mathrm{P}<0.01)$. Yem bitkilerinin kimyasal bileşimleri arasında olan farklılıklar yemlerin in vitro gaz üretimlerini ve gaz parametrelerini de etkilemiştir. Sonuç olarak, incelenen buğdaygil yem bitkilerinin geneli itibariyle ham protein, ham yağ ve ham kül bakımından zengin olan yemlerin diğer yemlere göre hücre duvarı bileşenleri bakımından fakir olanlarının in vitro gaz üretimi, metabolik enerji ve net enerji laktasyon ile organik madde sindirim özellikleri bakımından tatminkar sonuç ortaya koyduğu söylenebilir.
\end{abstract}

Anahtar Kelimeler: Besin madde bileşimi, Buğdaygil otları, İn vitro gaz üretimi

\section{Determination of In Vitro Gas Production Parameters of Some Grass Forages Grown as Naturally in The Pastures of Erzurum}

\begin{abstract}
This study was carried out to determine the in vitro gas production values, gas production parameters, organic matter digestibilities (OMD), metabolizable energy (ME), net energy lactation (NEL) and nutrients of some grass forages grown as naturally in the pastures of Erzurum province. In this study, 8 grasses [cocksfoot (Dactylis glomerata), crested wheatgrass (Agropyron cristatum), red fescue (Festuca rubra), sheep ball (Festuca ovina), tawny bromine (Bromus variegatus), blue split (Agropyron intermedium), kelp tail grass (Phleum pratense), meadow bluegrass (Poa pratensis)] were used. One Holstein bull with ruminal cannulas was used to get rumen fluid for gas production technique. Gas productions were determined at 3, 6, 9, 12, 24, 48, 72 and $96 \mathrm{~h}$. It was observed significant differences among the grass forages in terms of chemical composition (DM, crude ash, OM, CP, EE, NDF, ADF, $\mathrm{ADL}$, hemi sellulose, and sellulose) $(\mathrm{P}<0.01)$. The differences among the grass forages in the chemical composition affected the in vitro gas productions and gas production parameters of forages. The findings obtained from the present study generally showed that in vitro gas production, ME, NEL, OMD values of forages which were rich in $\mathrm{CP}, \mathrm{EE}, \mathrm{CA}$ and poor in $\mathrm{ADF}, \mathrm{NDF}, \mathrm{ADL}$ had convinging results according to other forages studied.
\end{abstract}

Keywords: Composition of Nutrient Matters, Cereal hay, In vitro Gas Production

\section{Giriș}

Günümüzde insanlarımızın temel beslenme kaynağının büyük bir kısmını tahıllar oluşturmaktadır. Ülkemiz çayır ve meralarında doğal olarak birçok yem bitkisi yetişmesine rağmen, çok az sayıda yem bitkisinin tarımı yapılmaktadır. Kültürü yapılan yem bitkileri tarımının tarla tarımı içindeki payı \% 20'dir (Anonim 2014). Tarımı gelişmiş ülkelerle kıyaslandığında bu oranın düşük olduğu ve arttırılması için 
yeni yem bitkisi tür ve çeşitlerinin tarla tarımına dahil edilmesi gerektiği bildirilmektedir (Başaran ve ark. 2006).

Yemlerde bulunan besin maddelerinin kullanım etkinlikleri onların sindirilebilirlikleri ile yakından ilişkilidir. Yemlerin sindirilme dereceleri başta klasik sindirim denemeleri olarak bilinen in vivo tekniklerin yanı sıra, hem laboratuvar hem de deney hayvanı gerektiren in situ teknik ve tamamen laboratuvar ortamında yürütülen in vitro teknikler yardımıla saptanabilmektedir (Kaya 2008; Kutlu 2008).

In vitro gaz üretimi tekniği yemlerin enerji değerleri ve sindirilebilirlik özelliklerinin belirlenmesinde kullanılan in vitro bir metottur. Bu yöntem diğer in vitro tekniklere oranla kaba yemlerin enerji değeri ve in vivo sindirilebilirliği hakkında daha iyi tahminler yapılmasına olanak sağlamaktadır (Menke ve ark. 1979; Theodorou ve ark. 1994; Kutlu 2008).

Ülkemizde, yem bitkileri tarımı henüz istenilen düzeylere ulaşamamıştır. Ayrıca, çayır ve meralarımızda doğal olarak yetişen çok sayıda kaliteli yem bitkisi olmasına rağmen, kültürü yapılan yem bitkileri, oldukça sınırlı sayı ve çeşittedir. Bu araştırma Erzurum ili ve ilçelerine ait meralarda yetişen bazı buğdaygil kaba yem bitkilerinin in vitro gaz üretim tekniği ile organik madde sindirilebilirliği, metabolik enerji ve net enerji laktasyon değerlerinin ortaya konulması amacıyla yürütülmüştür.

\section{Materyal ve Metot}

Araştırmanın yem materyalini, 2012 yılı Haziran-Temmuz aylarında Erzurum ili merkez ilçesi, Tortum, Narman, Çat, Şenkaya, Pasinler ve Oltu ilçelerinin meralarından toplanan domuz ayrığı (Dactylis glomerata), adi otlak ayrığı (Agropyron cristatum), kırmızı yumak (Festuca rubra), koyun yumağı (Festuca ovina), alaca brom (Bromus variegatus), mavi ayrık (Agropyron intermedium), çayır kelp kuyruğu (Phleum pratense) çayır salkım otu (Poa pratensis)'ndan oluşan 8 adet buğdaygil yem bitkisi oluşturmuş̧tur. Gelişme durumları izlenerek başaklanma devresinde hasat edilen bitkiler, hasat alanındaki bitki kompozisyonunu temsil edecek şekilde her bir bitki için 10 değişik yerden alınmış ve harmanlanmıştır (Karabulut ve Canbolat 2005; Canbolat ve Karaman 2009). Yem materyallerinin örneklendiği alanların koordinatları ve rakımları GPS cihazı ile belirlenerek kaydedilmiştir.

\section{Hayvan Materyali}

Çukurova Üniversitesi Ziraat Fakültesi İşletmesi Araştırma ve Uygulama Çiftliğinde yetiştirilen 8 yaşında ve $770 \mathrm{~kg}$ canlı ağılıkta olan Holstein ırkı kanüllü bir boğa hayvan materyalini oluşturmuştur. Ín vitro gaz üretim tekniği uygulamalarında söz konusu boğadan rumen sondası yardımıyla sabah yemlemesinden önce alınan rumen sıvısı kullanılmıştır. Rumen sıvısı alınan hayvan deneme süresince, mısır silajı ve yoğun yem karması (\% 17 ham protein, $2750 \mathrm{kcal} \mathrm{ME} / \mathrm{kg} \mathrm{KM}$ ) temeline dayanan rasyonla yemlenmiştir. Rasyonlarda kaba / yoğun yem oranı kuru madde temeline göre 60/40 olacak şekilde düzenlenmiştir.

\section{Kimyasal Analizler}

Yemlerin kimyasal analizi AOAC (1990)'da belirtilen yönteme göre, hücre duvarı bileşenleri, nötral deterjan fiber (NDF), asit deterjan fiber (ADF) ve asit deterjan lignin (ADL) tayinleri ise Van Soest ve ark. (1991).'nın bildirdikleri yöntemle ANKOM 200 Fiber Analyzer kullanılarak yapılmıı̧tır.

\section{In Vitro Gaz Üretim Tekniği}

Araştırmadaki yem örneklerinin toplam gaz üretiminin ölçülmesinde, in vitro gaz üretim testi modifiye edilerek uygulanmıştır (Menke ve ark. 1979; Menke ve Steingass 1988; Blümmel ve Ørskov 1993). Çalışmada, 1 mm'lik elekten geçecek şekilde öğütülmüş yem örneklerinden, $200 \mathrm{mg}$ kuru yem maddesi tartılarak enjektörün dibine yerleştirilmiştir. Yağlanan pistonlar dikkatli bir şekilde enjektörlere yerleştirilerek kayıt altına alınmak için numaralandırılmıştır. $400 \mathrm{ml}$ saf suya $0.1 \mathrm{ml}$ mikromineral çözeltisi, $200 \mathrm{ml}$ makromineral çözeltisi, $200 \mathrm{ml}$ rumen tampon çözeltisi, $1.0 \mathrm{ml}$ resazurin çözeltisi ve 40 $\mathrm{ml}$ indirgeme çözeltisi karıştırılarak vasat hazırlanmıştır. Daha sonra gaz üretimi amacıyla enjektörün içerisine $10 \mathrm{ml}$ rumen sıvısı ve $20 \mathrm{ml}$ vasat karışımdan konmuştur. Bu işlemden sonra tüpler $39^{\circ} \mathrm{C}$ 'deki su banyosunda inkübasyona alınmışlardır. Daha sonra sırasıyla inkübasyonun 3, 6, 9, 12, 24, 48, 72 ve 96. 
saatlerinde enjektörler içerisinde üretilen gaz miktarları saptanmıştır. Üretilen gaz miktarları, Ørskov ve McDonald (1979) tarafindan geliştirilen $\mathrm{y}=\mathrm{a}+\mathrm{b}\left(1-\mathrm{e}^{-\mathrm{ct}}\right)$ modeline göre Neway bilgisayar programında hesaplanmıştır.

Eşitlikte; $a=$ kolay çözünebilir fraksiyonların gaz miktarı $(\mathrm{ml}), \mathrm{b}=$ çözünemeyen fraksiyonların gaz üretim miktarı (ml), c = çözünemeyen fraksiyonların (b) gaz üretim oranı, $a+b=$ potansiyel gaz üretimi $(\mathrm{ml}), \mathrm{t}=$ inkübasyon süresi, saat $(\mathrm{s}), \mathrm{y}=\mathrm{t}$ süresince üretilen gaz miktarı

Yemlerin metabolik enerji değeri, organik madde sindirimi Menke ve ark. (1979)'nın, net enerji laktasyon değerleri ise Menke ve Steingass (1988)'ın bildirdiği denklemler kullanılarak hesaplanmıştır.

OMS $(\%)=14.88+0.889 \mathrm{GÜ}+0.45 \mathrm{HP}+0.65 \mathrm{HK}$

$\mathrm{ME}(\mathrm{MJ} / \mathrm{kg} \mathrm{KM})=2.20+0.136 \times \mathrm{GÜ}+0.057 \times \mathrm{HP}+0.002859 \times \mathrm{HY}^{2}$

$\mathrm{NEL}(\mathrm{MJ} / \mathrm{kg} \mathrm{KM})=0.101 \mathrm{GÜ}+0.051 \mathrm{HP}+0.112 \mathrm{HY}$

\section{Istatistik Analizler}

Araştırmada elde edilen veriler, SPSS 12.0 paket programı ile istatistiki olarak değerlendirilerek ortalamalar arasındaki farklılıkların saptanmasında varyans analizine (General Linear Model) tabi tutulmuştur. Gruplara ait ortalamaların karşılaştırılmasında ise Duncan çoklu karşılaştırma testi (Duncan 1955) kullanılmıştır. Yemlerin kimyasal kompozisyonu, gaz üretimi, gaz üretimi parametreleri ile ME, NEL, OMS arasındaki ilişki basit korelasyon analizlerine tabi tutularak belirlenmiştir (Snedecor ve Cochran 1976).

\section{Bulgular ve Tartışma}

\section{Yemlerin Kimyasal Bileşimi}

Erzurum merkez il ve ilçe meralarında doğal olarak yetişen buğdaygil yem bitkileri, bazı kimyasal özellikler (KM, HK, OM, HP, HY, NDF, ADF, ADL, Hemisellüloz ve Sellüloz) bakımından incelenmiş olup ve elde edilen sonuçlar Çizelge 1'de verilmiştir. İncelenen buğdaygil kaba yemlerine ait kimyasal bileşimler bakımından meydana gelen farklılıklar istatistiksel olarak önemli bulunmuştur $(\mathrm{P}<0.01)$.

Çizelge 1. Buğdaygil Yem Bitkilerinin Kimyasal Bileşimi, \% (KM’de)

\begin{tabular}{|c|c|c|c|c|c|c|c|c|c|c|}
\hline \multicolumn{11}{|c|}{ Kimyasal Bileşim } \\
\hline Yem Bitkileri & $\mathbf{K M}$ & HK & $\mathbf{O M}$ & HP & HY & NDF & ADF & ADL & $\begin{array}{l}\text { Hemi- } \\
\text { sellüloz }\end{array}$ & Sellüloz \\
\hline Adi otlak ayrığı & $94.83^{\mathrm{a}}$ & $5.68^{\mathrm{ab}}$ & $94.32^{\text {cd }}$ & $12.23^{\mathrm{ab}}$ & $2.76^{b}$ & $54.66^{d}$ & $27.19^{c}$ & $5.64^{\mathrm{ab}}$ & $27.47^{\mathrm{a}}$ & $21.56^{\mathrm{d}}$ \\
\hline Kırmızı yumak & $95.10^{\mathrm{a}}$ & $3.22^{\mathrm{d}}$ & $96.78^{\mathrm{a}}$ & $11.80^{\mathbf{a b}}$ & $2.65^{\mathrm{c}}$ & $61.65^{\mathrm{ab}}$ & $34.54^{\mathrm{a}}$ & $5.70^{\mathbf{a b}}$ & $27.11^{\mathrm{a}}$ & $28.84^{\mathbf{b}}$ \\
\hline Alaca brom & $94.73^{\mathrm{a}}$ & $5.35^{\mathrm{bc}}$ & $94.65^{\mathrm{bc}}$ & $13.03^{\mathrm{ab}}$ & $2.78^{\mathbf{b}}$ & $56.46^{\mathrm{d}}$ & $29.89^{\mathbf{b}}$ & $4.66^{\mathrm{b}}$ & $26.57^{\mathrm{a}}$ & $25.22^{c}$ \\
\hline Mavi ayrık & $93.30^{\mathbf{b}}$ & $5.35^{\mathrm{bc}}$ & $94.65^{\mathrm{bc}}$ & $13.49^{\mathrm{a}}$ & $3.53^{\mathrm{a}}$ & $57.54^{\text {cd }}$ & $28.53^{b c}$ & $3.18^{\mathrm{b}}$ & $29.01^{\mathrm{a}}$ & $25.34^{\mathrm{c}}$ \\
\hline Çayır kelp kuyruğu & $95.56^{\mathrm{a}}$ & $4.04^{\mathrm{cd}}$ & $95.96^{\mathbf{a b}}$ & $11.84^{\mathrm{ab}}$ & $1.33^{\mathrm{f}}$ & $64.48^{\mathrm{a}}$ & $34.90^{\mathrm{a}}$ & $5.57^{\mathrm{ab}}$ & $29.58^{\mathrm{a}}$ & $29.33^{\mathbf{a b}}$ \\
\hline Domuz ayrığı & $94.83^{\mathrm{a}}$ & $4.90^{\mathbf{b c}}$ & $95.10^{\mathbf{b c}}$ & $13.74^{\mathrm{a}}$ & $2.46^{\mathrm{d}}$ & $64.74^{\mathrm{a}}$ & $36.63^{\mathrm{a}}$ & $4.84^{\mathrm{b}}$ & $29.10^{\mathrm{a}}$ & $31.79^{\mathrm{a}}$ \\
\hline Çayır salkım otu & $95.10^{\mathrm{a}}$ & $5.77^{\mathrm{ab}}$ & $94.23^{\text {cd }}$ & $11.07^{\mathbf{b}}$ & $1.40^{\mathrm{f}}$ & $59.66^{\mathbf{b c}}$ & $29.97^{\mathbf{b}}$ & $4.47^{\mathbf{b}}$ & $29.68^{\mathrm{a}}$ & $25.50^{\mathrm{c}}$ \\
\hline Koyun yumağı & $92.63^{b}$ & $7.17^{\mathrm{a}}$ & $92.83^{d}$ & $11.01^{\mathrm{b}}$ & $2.22^{\mathrm{e}}$ & $33.41^{\mathrm{e}}$ & $23.29^{\mathrm{d}}$ & $7.54^{\mathrm{a}}$ & $10.12^{b}$ & $15.74^{\mathrm{e}}$ \\
\hline SEM & 0.288 & 0.359 & 0.737 & 0.476 & 0.230 & 0.76 & 0.587 & 0.572 & 0.817 & 0.681 \\
\hline Önemlilik Düzeyi & $* *$ & $* *$ & $* *$ & $* *$ & $* *$ & $* *$ & $* *$ & $* *$ & $* *$ & $* *$ \\
\hline
\end{tabular}

${ }^{a-f}$ Aynı sütunda farklı harfler ile gösterilen ortalamalar arasındaki farklılıklar önemlidir. ${ }^{* *}=\mathrm{P}<0.01$

SEM: Standart Hata Ortalamas1

Çalışmada ele alınan buğdaygil yem bitkisi örneklerine ait ham kül içerikleri \% 3.22-7.17 arasında değişmiştir. En yüksek ham kül içeriği \% 7.17 ile koyun yumağında, en düşük HK içeriği ise \% 3.22 ile kırmızı yumak yem bitkisinde tespit edilmiştir $(\mathrm{P}<0.01)$. Ham kül içeriği açısından koyun yumağı yem bitkisini rakamsal olarak, çayır salkım otu $>$ adi otlak ayrığı $>$ alaca brom $=$ mavi ayrık $>$ domuz ayrığg $>$ çayır kelp kuyruğu kuru otları takip etmiştir. Ham kül analizlerinde kül miktarı arta kalan organik madde içerikleri, \% 92.83-96.78 arasında değişmiştir. En yüksek organik madde içeriği \% 96.78 ile kırmızı yumakta, en düşük OM içeriği ise \% 92.83 ile koyun yumağında tespit edilmiştir. 
Çalışma sonucu elde edilen veriler konu ile ilgili yapılan diğer çalışmalarla kıyaslandığında ham kül ve organik madde içeriklerinin, kimi araştırıcıların bulguları ile uyumlu (Kamalak ve ark. 2005; Şahin ve ark. 2011; Canbolat 2012), kimi araştırıcıların bulgularından daha yüksek (Smoliak ve Bezeau 1967; Bayraktar 2005; Mohammadian-Tabrizi ve ark. 2011) ve kimi araştırıcıların bulgularından ise daha düşük (Akbaş ve ark. 2005; Kılıç ve ark. 2011) olduğu saptanmıştır.

Yemlerde bulunan ham protein miktarı yemin besleme değerini etkilemektedir. Protein oranının artması o yemin yem değerini yükseltmektedir. Ayrıca rumende mikrobiyal faaliyetlerin normal olarak gerçekleşebilmesi için, ruminant rasyonlarında en az \% 10 ham protein bulunması gerektiği bildirilmektedir (Norton 2012). Buğdaygil yem bitkileri örneklerine ait ham protein içerikleri saptanmış ve yemlerin ham protein içerikleri \% 11.01-13.74 arasında değişmiştir. En yüksek ham protein \% 13.73 ile domuz ayrığında, en düşük ise \% 11.01 ile koyun yumağında tespit edilmiştir $(\mathrm{P}<0.01) . \mathrm{Bu}$ yem bitkilerinden domuz ayrığını rakamsal olarak, mavi ayrık $>$ alaca brom $>$ adi otlak ayrığı > çayır kelp kuyruğu > kırmızı yumak > çayır salkım otu kuru otları takip etmiştir. Buğdaygil yem bitkileri ham protein içeriklerinin, kimi araştırıcıların (Bakır ve Açıkgöz 1976; Tosun 1992; Tansı ve ark. 1998; Bakoğlu ve ark. 1999) bulguları ile uyum içerisinde; bazı araştırıcıların bulgularından yüksek (Tükel ve Hatipoğlu 1994; Gökkuş ve ark. 1997; Serin ve ark. 1998; Mut 2003; Bayraktar 2005; Albayrak ve Ekiz 2005; Gül 2006; Şahin ve ark. 2010) ve kimi araştırıcıların bulgularından ise daha düşük (Smoliak ve Bezeau 1967; Serin 1991; Kılıç ve ark. 2011) olduğu tespit edilmiştir. Yem bitkilerinde bulunan ADF lignin, life bağlı azot, eriticilerde çözünmeyen mineralleri ile sellüloz gibi hücre duvarı bileşenlerini içerir. NDF ise ADF'ye ek olarak hemisellülozu da içerir. Buğdaygil otları sindirilebilirliğini güçleştiren ADL bakımından fakir olmalarına rağmen, hücre duvarı bileşenleri NDF, Hemisellüloz ve Sellüloz bakımından zengindir. Yemin NDF içeriği yem tüketimi ile ilgilidir. ADF içeriği ise kuru madde sindirilebilirliği ile ilişkili olup yemlerin net enerji içeriklerinin belirlenmesinde kullanılır. Bitkiler olgunlaştıkça bünyesinde ADF oranı artmaktadır.

Ayrıca, olgunlaşma ile buğdaygillerin gövde ve yapraklarında bulunan lignin içeriği 2 katına çıkarken, baklagillerde bu artış \% 20 düzeylerinde veya daha az olarak gerçekleşmektedir. Buğdaygillerde lignin/sellüloz oranı 0,94 olmakla birlikte lifli kısmına oranı baklagillerden daha yüksektir. Ruminantlar buğdaygil otlarında bulunann lifi \% 60-70 oranında sindirebilmektedirler (Smith ve ark. 1972; Buxton 1990; Van Soest ve ark. 1991; Buxton ve Mertens 1995; Buxton ve Redfearn 1996; Cherney ve ark. 1997; Rayburn 1997; Edward ve Rayburn 1998; Robinson 2003). Buğdaygil yembitkisi örneklerine ait hücre duvarı bileşenlerinden NDF içeriği \% 33.41-\% 64.74, ADF içeriği \% 23.29-36.63, ADL içeriği \% 3.18-7.54 arasında değişmiştir. En yüksek NDF içeriği, \% 64.74 ile domuz ayrığında, en düşük ise \% 33.41 ile koyun yumağında görülmüştür. Yine en yüksek ADF içeriği, \% 36.63 ile domuz ayrığında, en düşük ise \% 23.29 koyun yumağında görülmüştür. En yüksek ADL içeriğini, \% 7.54 ile koyun yumağ1 gösterirken, en düşük değeri ise \% 3.18 mavi ayrıkta tespit edilmiştir $(\mathrm{P}<0.01)$. Hemisellüloz bakımından en yüksek değer, \% 29.68 ile çayır salkım otunda, en düşük değer \% 10.12 ile koyun yumağında bulunurken, en yüksek sellüloz içeriği domuz ayrığında, en düşük ise \% 15.74 ile koyun yumağında tespit edilmiştir. Elde edilen veriler literatür çalışmaları ile kıyaslandığında, kimi araştırıcıların bulguları ile uyum içerisinde (Tan ve Menteşe 2003; Kılıç 2005; Kılıç ve ark. 2011; Canbolat 2012), kimi araştırıcıların bulgularından ise daha düşük (Kamalak 2005; Kamalak ve ark. 2005; Yavuz 2005; Şahin ve ark. 2011) olduğu tespit edilmiştir. Dumlu (2007), adi otlak ayrığı, mavi ayrık, domuz ayrığı ve çayır kelp kuyruğu silajlarının NDF oranlarını sirasıyla; \% 57.07, \% 58.39, \% 58.82 ve \% 57.09 olarak, ADF oranlarını ise yine aynı sırayla; \% 38.13, \% 38.15, \% 39.83 ve \% 41.12 olarak belirlemiştir. Yemin sindirim derecesinin yüksek olması, o yemin hücre duvarı bileşenlerinin düşük olmasına da bağlıdır. Bu nedenle yem içerisinde bulunan hücre duvarı bileşenlerinden ADF ve ADL içeriğinin düşük olması istenir (Van Soest 1994). Buğdaygil yem bitkilerinden ADF ve ADL bakımından en düşük değere sahip olan mavi ayrığın besleme değerinin daha iyi olduğu söylenebilir.

\section{Yemlerin In Vitro Gaz Üretim Değerleri}

Buğdaygil yem bitkilerine ait in vitro gaz üretim düzeyleri saptanmış ve Şekil 1'de verilmiştir. Buğdaygil yem bitkilerine ait 3-12 saatleri arasındaki inkübasyon süresince in vitro gaz üretim miktarları arasında önemli $(\mathrm{P}<0.01)$ farklılıklar bulunmuştur. 9 saatlik inkübasyon süreci sonunda adi otlak ayrığında $(6.63$ $\mathrm{ml}, 13.35 \mathrm{ml}$ ve $20.24 \mathrm{ml}), 12,24,48,72$ ve 96 saatlik inkübasyon sonrasında mavi ayrık $(26.27 \mathrm{ml}$, $40.43 \mathrm{ml}, 48.02 \mathrm{ml}, 49.35 \mathrm{ml}$ ve $51.30 \mathrm{ml}$ ) yem bitkisinde olduğu belirlenmiştir. En düşük gaz üretim miktarının ise $3,6,9,12$ ve 24 saatlik inkübasyon sonunda çayır salkım otunda $(1.00 \mathrm{ml}, 2.62 \mathrm{ml}, 5.11$ 
$\mathrm{ml}, 8.34 \mathrm{ml}$ ve $22.32 \mathrm{ml}), 48,72$ ve 96 saatlik inkübasyon süreci sonunda ise koyun yumağ $(30.76 \mathrm{ml}$, $31.98 \mathrm{ml}$ ve $33.01 \mathrm{ml}$ ) yem bitkisinde tespit edilmiştir.

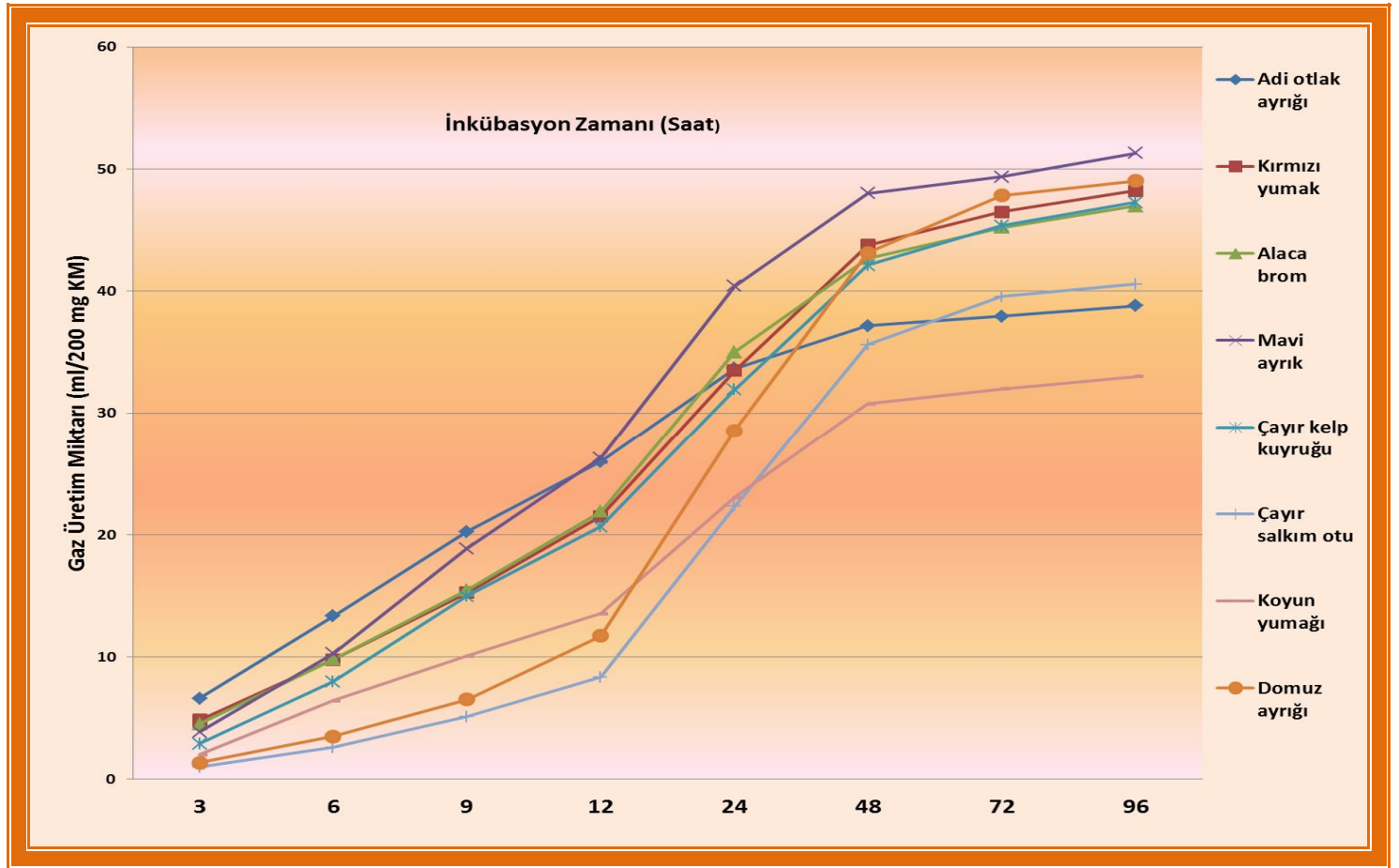

Şekil 1. Buğdaygil yem bitkilerine ait in vitro gaz üretim miktarları

Çalışmada incelenen buğdaygil kaba yemlerinden çayır salkım otu ve koyun yumağının diğer buğdaygil kaba yemlerine göre daha az in vitro gaz üretmeleri konusu kaba yemleri protein ve yararlanılabilir NDF bakımından fakir, ADF ve ADL bakımından ise zengin olmalarından kaynaklanmış olabilir. Koyun yumağının hücre duvarı bileşenlerinin düşük olması, gaz üretimini artıran asetik asit üretiminin de düşük olması anlamına gelebilir bu nedenle düşük gaz üretiminin olacağı beklenilmelidir. Buna göre düşük gaz üretimi, fenolik maddeler içeriğinden de kaynaklanmış olabilir (Kılıç ve Sarıçiçek 2008). Yemlerde NDF, ADF ve ADL miktarlarının düşmesine bağlı olarak enerji ve protein içeriğinin artmasıyla, gaz üretiminin olumlu etkilendiği söylenebilir (Cone ve Gelder 1999; Anonim 2001; Filya ve ark. 2002; Blümmel ve ark. 2003; Aydın ve ark. 2007; Karabulut ve ark. 2007; Canbolat ve Karaman 2009).

Buğdaygil yem bitkilerine ait in vitro gaz üretim değerlerinin, bu konuda yapılan bazı çalışmalarda elde edilen bulgular ile uyum içerisinde (Kamalak 2005; Kılıç ve ark. 2011), bazı çalışmaların bulgularından ise daha düşük (Filya ve ark. 2002; Cruywagen ve Bunge 2004; Abaş ve ark. 2005; Kamalak ve ark. 2005a; b; Kılıç 2005; Aydın 2008; Şahin ve ark. 2011; Canbolat 2012) olduğu tespit edilmiştir. Söz konusu farklılıkların, yemlerin besin madde içerikleri, tür ve çeşit farklılıkları, hasat gibi faktörlerden kaynaklanabileceği, araştırıcılar tarafından bildirilmiştir (Kılıç 2005; Kılıç ve Sarıçiçek 2006).

Söz konusu buğdaygil yem bitkilerine ait in vitro gaz üretim parametreleri saptanmış ve Çizelge 2'de verilmiştir. Yemlerin a ve b parametreleri arasındaki farklılıklar önemli bulunurken $(\mathrm{P}<0.05)$, c ve $\mathrm{a}+\mathrm{b}$ parametreleri arasındaki farklılıkların ise önemli olmadığı saptanmıştır $(\mathrm{P}>0.05)$.

Bir yemin " a" değeri yemin enjektöre konulduğu ilk anda hemen çözünebilir fraksiyondan kaynaklanan gaz üretimini belirtmektedir. Bu değer yemlerdeki ham protein ve hücre duvarı bileşenlerinin (NDF, ADF ve ADL) miktarına bağlı olarak değişmektedir. Deneme kapsamında incelenen buğdaygil yem bitkilerine ait "a" değerleri açısından en yüksek değer koyun yumağında $(-2.76 \mathrm{ml})$, en düşük değer ise mavi ayrık $(-8.59 \mathrm{ml})$ yem bitkisinde tespit edilmiştir. 
Çizelge 2. Buğdaygil yem bitkilerinine ait in vitro gaz üretim parametreleri

\begin{tabular}{|c|c|c|c|c|}
\hline \multirow[b]{2}{*}{ Yem Bitkileri } & \multicolumn{4}{|c|}{ İnkübasyon Parametreleri } \\
\hline & $\mathbf{a}, \mathbf{m l}$ & $\mathbf{b}, \mathbf{m l}$ & c, ml/saat & $\mathbf{a}+\mathbf{b}, \%$ \\
\hline Adi otlak ayrığı & $-6.20^{\mathrm{bcd}}$ & $48.17^{\mathrm{a}}$ & 0.12 & 41.97 \\
\hline Kırmızı yumak & $-3.46^{\mathrm{ab}}$ & $51.79^{\mathrm{a}}$ & 0.05 & 48.34 \\
\hline Alaca brom & $-4.66^{\mathrm{abc}}$ & $51.09^{\mathrm{a}}$ & 0.06 & 46.44 \\
\hline Mavi ayrik & $-8.59^{\mathrm{d}}$ & $59.08^{\mathrm{a}}$ & 0.07 & 50.49 \\
\hline Çayır kelp kuyruğu & $-4.94^{\mathrm{abc}}$ & $51.83^{\mathrm{a}}$ & 0.05 & 46.89 \\
\hline Domuz ayrı̆̆ & $-7.63^{\mathrm{cd}}$ & $59.66^{\mathrm{a}}$ & 0.04 & 52.03 \\
\hline Çayır salkım otu & $-6.27^{\mathrm{bcd}}$ & $50.07^{\mathrm{a}}$ & 0.04 & 43.81 \\
\hline Koyun yumağı & $-2.76^{\mathrm{a}}$ & $36.17^{\mathrm{b}}$ & 0.05 & 33.42 \\
\hline SEM & 0.994 & 3.779 & 0.021 & 4.538 \\
\hline Önemlilik Düzeyi & $*$ & $*$ & ns & ns \\
\hline
\end{tabular}

Yem bitkilerinin zamana bağlı olarak oluşan gaz miktarının bir ifadesi olan 'b" değeri bakımından en yüksek değer domuz ayrığı (59.66 ml), en düşük değer ise koyun yumağ1 (36.17 ml) yem bitkilerinde belirlenmiştir. Buğdaygil yem bitkileri içinde en yüksek 'c"' değeri adi otlak ayrı̆̆ından (0.12 ml/saat), en düşük değer ise domuz ayrığı ve çayır salkım otundan $(0.04 \mathrm{ml} / \mathrm{saat})$ elde edilmiştir. Yem bitkilerinin potansiyel gaz üretim miktarının (toplam gaz üretimi) bir ifadesi olan " $a+b$ " değeri bakımından en yüksek değer domuz ayrığında $(52.03 \mathrm{ml})$, en düşük değer koyun yumağında (33.42 ml) tespit edilmiştir. Potansiyel gaz üretiminin 96 saatlik fermantasyon süreci sonunda saptanan in vitro gaz üretim miktarları ile benzer olduğu bildirilmektedir (Canbolat ve Karaman 2009).

Buğdaygil yem bitkilerine ait gaz üretim parametreleri konu ile ilgili olarak yapılan diğer çalışmalar ile kıyaslandığında, araştırma bulgularının ' a', ' b', ' "c" ve " a+b' değerleri, kimi araştırıcıların bulguları ile uyum içerisinde (Kamalak 2005; Kamalak ve ark. 2005a; Kamalak ve ark. 2005b; Kılıç 2005; Kılıç ve ark. 2011; Şahin ve ark. 2011), kimi araştırıcıların bulgularından ise daha düşük (Aydın 2008; Tang ve ark. 2008 olduğu tespit edilmiştir.

\section{Yemlerin ME, NEL ve OMS içerikleri}

Buğdaygil yem bitkilerine ait organik madde sindirilebilirliği, metabolik enerji ve net enerji laktasyon değerleri saptanmış ve Çizelge 3'te verilmiştir. Buğdaygil yem bitkilerine ait organik madde sindirilebilirliği (OMS), metabolik enerji $(\mathrm{ME})(\mathrm{P}<0.05)$ ve net enerji laktasyon (NEL) içerikleri arasındaki farklılıkların önemli $(\mathrm{P}<0.01)$ olduğu belirlenmiştir. Yemler arasındaki çeşit farklılıklarının OMS ve enerji içeriklerini etkilediği ayrıca hesaplamada kullanılan eşitlikler ve gaz üretim miktarı (24 saatlik) elde edilen sonuçlarla doğru orantılı olarak etkilenmiştir (Kılıç 2005).

Çizelge 3. Buğdaygil yem bitkilerinine ait organik madde sindirilebilirlikleri (\%), metabolik enerji $(\mathrm{MJ} / \mathrm{kg} \mathrm{KM})$ ve net enerji laktasyon $(\mathrm{MJ} / \mathrm{kg} \mathrm{KM})$ değerleri

\begin{tabular}{|c|c|c|c|}
\hline Yem Bitkileri & OMS & ME & NEL \\
\hline Adi otlak ayrığı & $50.64^{\mathrm{ab}}$ & $7.19^{\text {abc }}$ & $4.15^{\text {abcd }}$ \\
\hline Kırmızı yumak & $50.46^{\mathbf{a b}}$ & $7.47^{\text {abc }}$ & $4.33^{\mathrm{abc}}$ \\
\hline Alaca brom & $52.53^{\mathrm{ab}}$ & $7.75^{\mathrm{ab}}$ & $4.57^{\mathrm{ab}}$ \\
\hline Mavi ayrık & $56.88^{\mathrm{a}}$ & $8.42^{\mathrm{a}}$ & $5.16^{\mathrm{a}}$ \\
\hline Çayır kelp kuyruğu & $49.77^{\mathbf{a b}}$ & $7.37^{\mathbf{a b c}}$ & $4.11^{\text {abcd }}$ \\
\hline Domuz ayriğ & $45.85^{\mathbf{b c}}$ & $6.76^{\mathrm{bc}}$ & $3.77^{\text {bed }}$ \\
\hline Çayır salkım otu & $40.31^{\mathrm{c}}$ & $5.90^{\mathrm{c}}$ & $3.01^{\mathrm{d}}$ \\
\hline Koyun yumağı & $46.02^{b c}$ & $6.10^{c}$ & $3.27^{\mathrm{cd}}$ \\
\hline SEM & 2.533 & 0.360 & 0.269 \\
\hline Önemlilik Düzeyi & $*$ & $* *$ & $* *$ \\
\hline
\end{tabular}

a-d Aynı sütunda farklı harfler ile gösterilen ortalamalar arasındaki farklılıklar önemlidir. SEM= Standart Hata Ortalaması. $\mathrm{OMS}=$ Organik madde sindirilebilirliği, $\mathrm{ME}=$ Metabolik enerji, $\mathrm{NEL}=\mathrm{Net}$ enerji laktasyon, ${ }^{*}=\mathrm{P}<0.05$, $* *=\mathrm{P}<0.01$ 


\section{E. GÜRSOY, M. MACITT}

Araştırma materyali buğdaygil yem bitkilerine ait organik madde sindirilebilirliği değerleri, \% 40.31 56.88 arasında değişmiştir. En yüksek OMS değeri en yüksek mavi ayrıkta (\% 56.88), en düşük ise çayır salkım otunda (\% 40.31) belirlenmiştir. Buğdaygil kaba yemlerinin HP ve HK içeriği ile 24. saatte ürettikleri gaz miktarının artması OMS düzeyini de artırmıştır. Ayrıca araştırma bulguları değerlendirildiğinde NDF, ADF ve ADL gibi rumende çözünmesi zor olan besin maddelerince zengin olan yemlerin, mikrobiyal fermantasyonu sınırlandırarak OMS miktarını düşürebileceği bazı araştırıcılar tarafindan bildirilmiştir (Umucalılar ve ark. 2002; Canbolat ve Karaman 2009; Kılıç ve ark. 2011). Yemlerin ME ve NEL içerikleri sırasıyla; 5.90 ile $8.42 \mathrm{MJ} / \mathrm{kg} \mathrm{KM}$ ve $3.01-5.16 \mathrm{MJ} / \mathrm{kg} \mathrm{KM}$ arasında değişmiştir. En yüksek ME ve NEL değeri mavi ayrıktan (8.42 MJ/kg KM ve $5.16 \mathrm{MJ} / \mathrm{kg} \mathrm{KM})$, en düşük ME ve NEL'nin ise çayır salkım otu (5.90 MJ/kg KM ve $3.01 \mathrm{MJ} / \mathrm{kg} \mathrm{KM}$ ) yem bitkisinden elde edilmiştir.

Çayır salkım otunun OMS, ME ve NEL içeriklerinin düşük çıkması, HP ve 24. saatteki gaz üretim miktarının, diğer buğdaygil yem bitkilerinden daha düşük olması ve yemlerin sindirilebilirliğini zorlaştıran hücre duvarı bileşenlerinin (NDF, ADF ve ADL) artmasından kaynaklanmış olabilir. Söz konusu buğdaygil yem bitkilerine ait OMS, ME ve NEL değerleri, konu ile ilgili yapılan bazı çalışmalardan elde edilen bulgularla uyumlu (Kamalak 2005; Kılıç vd. 2011), bazı araştırıcıların bulgularından (Tang ve ark. 2008) yüksek, kimi araştırıcıların bulgularından ise düşük (Aydın 2008; Canbolat 2012) bulunmuştur.

\section{Sonuç}

Araştırma kapsamında ele alınan buğdaygil yem bitkilerinin kimyasal bileşimleri bakımından önemli farklılıklar tespit edilmiştir. Buğdaygil yem bitkilerinin kimyasal bileşimleri arasındaki farklılıklar yemlerin in vitro gaz üretimlerini $(3,6,9,12,24$ saat) ve bazı gaz parametrelerini de (a, b) etkilemiştir. İn vitro gaz üretim değeri (24. saat) ve bazı kimyasal bileşimleri dikkate alınarak hesaplanan OMS, ME ve NEL değerleri en yüksek mavi ayrıkta, en düşük ise çayır salkım otunda tespit edilmiştir. Mavi ayrık otu OMS, ME ve NEL değerleri bakımından da diğer yemlerden yüksek saptanmıştır.

\section{Teșekkür}

Bu çalışma 2011/334 proje numarasıyla Atatürk Üniversitesi BAP fonu tarafından desteklenmiş, Prof. Dr. Muhlis MACİT danışmanlığında Esra GÜRSOY'un Doktora Tez çalışmasından alınmıştır.

\section{Kaynaklar}

Abaş İ, Özpınar H, Kutay HC, Kahraman R, Eseceli H (2005). Determination of the Metabolizable Energy (ME) and Net Energy Lactation (NEL) Contents of Some Feeds in the Marmara Region by in vitro Gas Tecnique. Turk J. Vet. Anim. Sci., 29: 751-757.

Albayrak S, Ekiz H (2005). An Investigation on the Estabilishment of Artifical Pasture Under Ankara's Ecological Conditions. Turk J. Agric For., 29: 69-74.

Anonim (2001). 04.07.2013. From Feed To Milk: Understanding Rumen Function. http://wwwdas.cas.psu.edu/den/catnut/422/index.html.

Anonim (2014). Türkiye istatistik kurumu (http://tuik.gov.tr) Erişim tarihi 26.08.2014.

AOAC (1990). Official Method of Anallysis. Association of Official Analytical Chemists pp. 66-88. 15 th.edition Washington, DC. USA.

Aydin R, Kamalak A, Canbolat O (2007). Effect of Maturity on The Potential Nutritive Value of Bur Medic Hay. Journal of Biological Sciences 7 (2): 300-304.

Aydın D (2008). İn Vitro Gaz Üretim Tekniğinde Gübrenin Rumen Sıvısı Yerine Kullanımı. Yüksek Lisans Tezi, K.S.İ.Ü. Fen. Bil. Ens., Kahramanmaraş.

Bakır Ö, Açıkgöz E (1976). Otlak Ayrığı (Agropyrom cristatum L. Gaern.) Bitkisinin Çeşitli Organlarında Kimyasal Kompozisyonun Gelişme Devrelerine Göre Değişimi. A.Ü.Z.F. Yıllığı, 26: 346-353.

Bakoğlu A, Koç A, Gökkuş A (1999). Erzurum Yöresi Çayır-Meralarındaki Yaygın Bitki Türlerinin Ömür Uzunluğu, Çiçeklenmeye Başlama Tarihi ve Ot Kalitesi İle İlgili Bazı Özellikleri. Tr. J. of Agriculture and Foresty, 23 (4): 951-957.

Başaran U, Acar Z, Mut H, Aşcı ÖÖ (2006). Doğal Olarak Yetişen Bazı Baklagil Yem bitkilerinin Bazı Morfolojik ve Tarımsal Özellikleri. OMÜ Zir. Fak. Dergisi, 21 (3): 314-317. 
Bayraktar E (2005). Tekirdağ Koşullarında Bazı Yem bitkilerinin Farklı Gelişme Dönemlerinde Kök ve Gövdelerinde Bitkilerin Kimi Besin Maddelerinin Değişimi. Yüksek Lisans Tezi. Tarla Bitkileri Ana Bilim Dalı, Tekirdağ.

Beuvink JMW, Spoelstra SF (1992). Interactions Between Substrate, Fermentation End-Products, Buffering Systems and Gas Production upon Fermentation of Different Carbohydrates by Mixed Rumen Microorganisms in vitro. Applied Microbiology and Biotechnology, 37: 505-509.

Blümmel M, Ørskov ER (1993). Comparison of in vitro gas Production and Nylon Bag Degradabilities of Roughages in Predicting Food Intake of Cattle. Anim. Feed Sci. and Technol. 40: 109-119.

Blümmel M, Karsli A, Russell JR (2003).Influence of Diet on Growth Yields of Rumen MicroOrganisms in vitro and in vivo:Influence on Growth Yield of Variable Carbon Fluxes to Fermentation Products.British J.of Nutr. 90:625-634.

Buxton DR, Mertens DR (1995). Ouality-Related Characteristics of Forages in Forages Volume II. The Science of Grassland Agriculture, Lowa State Univ. Pros., Ames, Lowa, USA, 83-96.

Buxton DR, Redfearn DD (1996). Plant Limitations to Fiber Digestion and Utilization. 37th. Annual Ruminant Nut. Conf., 14 April, Washington, 814-818.

Canbolat Ö, Karaman Ş (2009). Bazı Baklagil Kaba Yemlerinin in Vitro Gaz Üretimi, Organik Madde Sindirilebilirliği, Nispi Yem Değeri ve Metabolik Enerji İçeriklerinin Karşılaştırılması. Tarım Bilimleri Dergisi, 15 (2): 188-195. Ankara.

Canbolat Ö (2012). Bazı Buğdaygil Kaba Yemlerinin in vitro Gaz Üretimi, Sindirilebilir Organik Madde Nispi Yem Değeri ve Metabolik Enerji İçeriklerinin Karşılaştırılması. Kafkas Üniv. Vet. Fak. Derg., 18(4): 571-577.

Cherney DJR, Cherney JH, Davidson AH (1997). Characterization of Legume and Grass Residues Following in vitro and in sacco Ruminal Digestion. XVIII. International Grassland Cong., June 8-17, Winnipeg and Saksatoon, 17: 17-23.

Cone JW, Van Gelder AH, Soliman IA, De Visser H, Van Vuuren AM (1999). Different Techniques to Study Rumen Fermentation Characteristics of Maturing Grass and Grass Silage. J. Dairy Sci. 82: 957-966.

Cruywagen CW, Bunge GA (2004). The Effect of Supplemental Biotin in Dairy Cow Diets on Fibre Fermentation Patterns as Measured by in vitro gas Production. South African Journal of Animal Science. 34 (suppl. 2): 68-70.

Dumlu Z (2007). Erzurum Şartlarında Bazı Çok Yıllık Baklagil ve Buğdaygil Yem Bitkilerinin Silajlık Kullanımları Üzerine Bir Araştırma. Yüksek Lisans Tezi, Atatürk Üniv. Fen Bil. Enst. Erzurum.

Duncan DB (1955). Mutiple Range and Multiple F Tests. Biometrics, 11: 1-42.

Edward B, Rayburn Ph. D (1998). Using of Forage Test to Identify Improvements in Forage Management West Virginia Univ. Extension Service, PO Box 6108, Morgantown.

Filya I, Karabulut A, Canbolat O, Degirmencioglu T, Kalkan H (2002). Bursa Bölgesinde Yetiştirilen Yem Hammaddelerinin Besleme Değeri ve Hayvansal Organizmada Optimum Değerlendirme Koşullarının in vivo ve in vitro Yöntemlerle Saptanması Üzerinde Araştırmalar. U.Ü. Ziraat Fakültesi Bilimsel Araştırmalar ve İncelemeler Serisi. No:25, Bursa, 1-16.

Gökkuş A, Koç A, Bakoğlu A (1997). Otlak Ayrığı (Agropyron cristatum Gaertn.)'nın Bazı Morfolojik, Agronomik ve Kimyasal Özelliklerinin Zamana, Bitki Boyuna ve Toprak Üstü Biomasına Bağlı Olarak Değişimi. Tarla Bitkileri Merkez Araşt. Enst. Derg. 6: 49-61.

Gül E (2006). Bazı Buğdaygil Yem Bitkilerinin Verim ve Verim Öğelerinin Belirlenmesi. Yüksek Lisans Tezi, Ankara Ünv. Fen Bil. Enst., Ankara.

Kamalak A (2005). Bazı Kaba Yemlerin Gaz Üretim Parametreleri ve Metabolik Enerji İçerikleri Bakımdan Karşılaştırılması. KSÜ. Fen ve Mühendislik Dergisi, 8(2).

Kamalak A, Canbolat Ö, Gürbüz Y, Erol A, Özay O (2005). Effect of maturity stage on chemical composition, in vitro and in situ dry matter degradation of tumbleweed hay (Gundelia tournefortii L.). Small Rum. Research, 58: 149-156.

Kamalak A, Canbolat Ö, Gürbüz Y, Özay O (2005a). Prediction of Dry Matter Intake and Dry Matter Digestibilities of Some Forges Using the Gas Production Teqnique in Sheep. Turk J. Vet. Anim. Sci. 29: 517-523.

Kamalak A, Canbolat Ö, Gürbüz Y, Özay O (2005b). Comparison of in Vitro Gas Production Technique With in Situ Nylon Bag Technique to Estimate Dry Matter Degradation. Czech J. Anim. Sci., 50 (2): 60-67.

Karabulut A, Canbolat Ö, Kalkan H, Gürbüzol F, Sucu, E, Filya İ (2007). Comparison of in vitro Gas Production, Metabolizable Energy, Organic Matter Digestibility and Microbial Protein Production of Some Legume Hays. Asian-Agust. J. Anim. Sci. 20 (4): 517-522. 
Kaya Ş (2008). Kaba Yemlerin Değerlendirilmesinde Göreceli Yem Değeri ve Göreceli Kaba Yem Kalite İndeksi. Türk Bilimsel Derlemeler Dergisi, 1 (1): 59-64.

Kılıç A (2006). Kaba Yemlerde Niteliğin Saptanması.Yardımcı Ders Kitabı. Hasad Yayıncılık, 159 s.

Kılıç Ü (2005). Ruminant Beslemede Kullanılan Bazı Yem Hammaddelerinin in vitro Gaz Üretim Tekniği Kullanılarak Bazı Fermentasyon Ürünlerinin ve Enerji İçeriklerinin Belirlenmesi. Doktora tezi. O.M.Ü. Fen Bil. Enst. Samsun.

Kılıç Ü, Sarıçiçek BZ (2006). In Vitro Gaz Üretim Tekniğinde Sonuçları Etkileyen Faktörler. Hayvansal Üretim, 47 (2): 54-61.

Kılıç Ü, Yurtseven S, Boğa M, Aydemir S (2011). Bazı Buğdaygil Yem Bitkilerinin Besin Madde İçerikleri ve In Vitro Gaz Üretimi Üzerine Toprak Tuzluluk Düzeylerinin Etkisi. 7. Ulusal Zootekni Bilim Kongresi, Adana.

Kutlu HR (2008). Yem Değerlendirme ve Analiz Yöntemleri. Çukurova Üniversitesi Ziraat Fakültesi Zootekni Bölümü. Ders notu. Z.M. 208. Adana.

Menke KH, Raab LL, Salewski A, Steingass H, Fritz Schneider W (1979). The Estimation of Digestibility and Metabolizable Energy Content of Ruminant Feeding Stuffs From The Gas Production When They are Incubated With Rumen Liqueur in vitro. Journal of Agricultural Science, 93: 217-222.

Menke KH, Steingass H (1988). Estimation of the Energetic Feed Value Obtained from Chemical Analysis and in vitro Gas Production Using Rumen Fluid. Anim. Res. Devel., 28: 7-55.

Mohammadian-Tabrizi HR, Sadeghipanah H, Chamani M, Ebrahim-Nejad Y, Fazali H (2011). In Vitro Gas Production of Wheat Grain Flour Coated With Different Fat Types and Levels. African J. of Biotechnology, 10 (39): 7710-7716.

Mut H (2003). O.M.Ü. Kurupelit Yerleşkesinin Farklı Yerlerinde Yetişen Domuz Ayrığı (Dactylis glomerata ssp. Glomerata L.) Bitkilerinin Bazı Fenolojik, Morfolojik, Tarımsal Özelliklerinin Belirlenmesi. O.M.Ü. Zir. Fakültesi Yüksek Lisans Tezi, Samsun.

Norton BW (2012). The Nutritive Value of Tree Legumes. Erişim tarihi, 07.11.2012. http://www.fao.org /ag/AGP/AGPC/doc/Pubicat/Gutt-shel/x5556e0j.htm. pp. 1-10.

Ørskov ER, McDonald I (1979). The Estimation of Protein Degrability in the Rumen From İncubation Measurements Weighted According to Rate of Passge. J. Agric. Sci. Camb. 92: 499-503.

Pell AN, Schofield P (1993). Computerized Monitoring of Gas production to Measure Forage Digestion. J. Dairy Sci. 76: 1063-1073.

Rayburn EB (1997). 06.11.2012 from www.caf.wvu.edu/ forage.

Robinson PH (2003). Estimating Alfalfa Hay and Corn Silage Energy Levels,UC Davis Equations Using NDF and ADF.06.11.2012, from http://animalscience.ucdavis.edu/faculty/robinson /Articles/Fulltext/Pdf/Web200309.pdf.

Serin Y (1991). Erzurum Kıraç Şartlarında Yetiştirilen Mavi Ayrık (Agropyron intermedium (Host.) Beauv.)' a Uygulanan Değişik Sıra Aralığı ve Gübrelerin Ot ve Ham Protein Verimi ile Otun Ham Protein Oranına Etkileri Üzerine Bir Araştırma. Atatürk Üniv. Zir. Fak. Der. 22 (2): 1-13.

Serin Y, Gökkuş A, Tan M, Koç A, Çomaklı B (1998). Sun’i Çayır Tesisinde Kullanılabilecek Uygun Yem bitkileri ve Karışımlarının Belirlenmesi. Tr. J. Of Agriculture and Foresty. 22: 13-20.

Snedecor GW, Cochran W (1976). Statistical Methods. The Iowa State Univ. Pres. Amer. IA. USA.

Smoliak S, Bezeau LM (1967). Chemical Composition and In Vitro Digestibility of Range Forage Plants of The Stipa-Bouteloua Praire. Can. J. Plant Sci. Vol. 47.

Şahin E, Tosun M, Haliloğlu K, Aydın M (2010). Yabani Domuz Ayrığının (Dactylis glomerata L.) Oltu Ekotipine Ait Hatlarda Bazı Tarımsal ve Kalite Özellikleri. Süleyman Demirel Üniv. Zir. Fak. Der. 5 (1): 24-35.

Şahin M, Üçkardeş F, Canbolat Ö, Kamalak A, Atalay Aİ (2011). Ruminant Beslemede Kullanılan Bazı Yemlerin Kısmi Gaz Üretim Zamanlarının Tahmini. Kafkas Univ. Vet. Fak. Derg., 17 (5): 731 734.

Tan M, Menteşe Ö (2003).Yem bitkilerinde Anatomik Yapı ve Kimyasal Kompozisyonun Besleme Değerine Etkileri. Atatürk Üniv. Ziraat Fak. Derg., 34(1): 97-103.

Tang SX, Tayo ZL, Sun, ZH, Wang M, Ren GP, Han XF (2008). Use of in vitro Gas Production Tecnique to Investigate Interactions Between Rice Straw, Wheat Straw, Maize Stover and Alfalfa or Clover. Asian-Aust. J.Anim. Sci. 21 ( 9): 1278-1285.

Tansı V, Okan F, Kızıl S, Kızılşimşek M (1998). Çukurova Koşullarında Bazı Buğdaygillerin Toprak Üstü Bioması ve Kimyasal Kompozisyonların Mevsimsel Değişiminin Saptanması. Ç.Ü.Z.F. Derg., 13 (3): 1-18. 
Theodorou MK, Williams BA, Dhannoa MS, Mcallan AB, France J (1994). A Simple Gas Production Method Using A Pressure Transducer to Determine The Fermentation Kinetics of Ruminant Feeds. Anim. Feed Sci. Technol. 48: 185-197.

Tosun M (1992). Erzurum Yöresinde Doğal Olarak Yetişen Domuz Ayrı̆̆ı Bitkilerinin Bazı Morfolojik, Fenolojik ve Sitolojik Özelliklerinin İncelenmesi. Yüksek Lisan Tezi. Atatürk Ünv. Fen Bil. Enst. Ziraat Fak. Erzurum.

Tükel T, Hatipoğlu R (1994). Çukurova Bölgesinde Bulunan Doğal Domuz Ayrığı (Dactylis glomerata L.) Bitkisinin Morfolojik, Biyolojik ve Tarımsal Karakterleri Üzerine Araştırmalar. Tarla Bitkileri Kongresi, Cilt 3, Çayır Mer'a Yem bitkileri Bildirileri, 25-29 Nisan, İzmir, 44-47.

Van Soest PJ, Robertson JD, Lewis BA (1991). Methods for Dietary Fibre, Neutral Detergent Fibre and Non-starch Polysaccharides in Relation to Animal Nutrition. Journal of Dairy Science, 74: 35833597.

Van Soest PJ (1994). Nutritional Ecology of the Ruminant (2nd Ed.). Ithaca, N.Y. Cornell University Press.

Waghorn GC, Stafford KJ (1993). Gas Production and Nitrojen Digestion by Rumen Microbes From Deer and Sheep. New Zealand J. Agric. Res. 36: 493-497.

Yavuz M (2005). Bazı Ruminant Yemlerinin Nispi Yem Degeri ve in vitro Sindirim Degerlerinin Belirlenmesi. GOÜ. Ziraat Fakültesi Dergisi, 22 (1): 97-101. 